\title{
Combining phytoextraction by Brassica napus and biochar amendment for the remediation of a mining soil in Riotinto (Spain)
}

\author{
G. Gasco, M.L. Álvarez, J. Paz-Ferreiro, A . Méndez
}

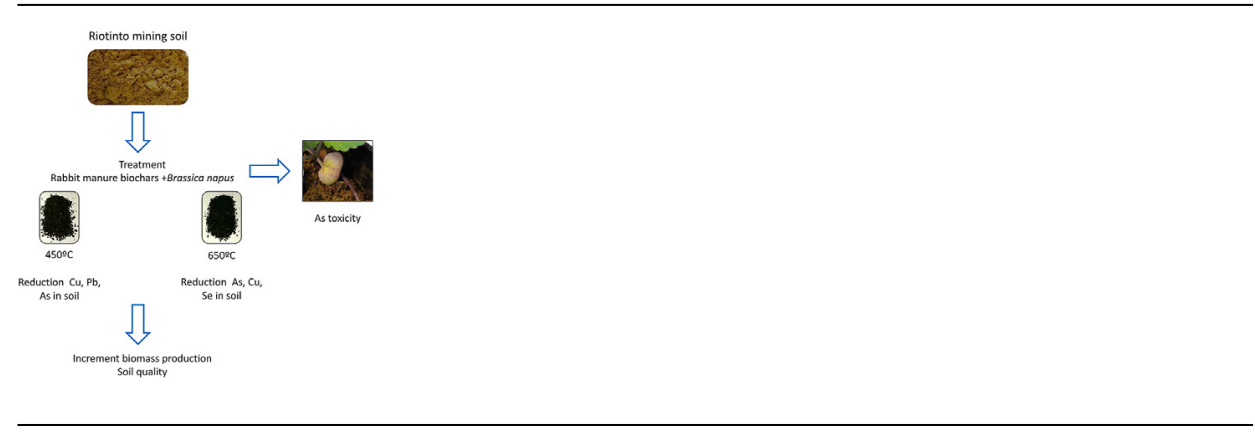

\begin{abstract}
A B S T R A C T
Soil contamination in mining areas is an important environmental concern. In these areas, phytoremediation is often impeded because of the low fertility and $\mathrm{pH}$. Assisted phytoremediation is increasingly being used in polluted areas. Biochar could assist plant growth via enhanced soil fertility. An experiment was performed in a mining soil (RIII) from the mining area of Riotinto (Spain) contaminated with $\mathrm{Cu}, \mathrm{Pb}, \mathrm{Zn}$ and As in order to study: (i) The effects of biochar on soil fertility; (ii) Biochar temperature of preparation effect and (iii) Effect of biochar on phytoremediation potential. A mesocosm experiment was designed using Brassica napus as test specie. Soil (RIII) was treated with rabbit manure biochars prepared at $450{ }^{\circ} \mathrm{C}(\mathrm{BM} 450)$ and $600{ }^{\circ} \mathrm{C}$ (BM600) at a rate of $10 \%$ in mass and incubated for 60 days with or without Brassica napus. Results showed that the combination of BM450 or BM600 with Brassica napus growth decreased the amount of $\mathrm{As}, \mathrm{Cu}, \mathrm{Co}, \mathrm{Cr}$, Se and $\mathrm{Pb}$ in the soil. Values of bioaccumulation factor (BAF) for $\mathrm{Cd}$ were particularly elevated $(>10)$ in the unamended soil and reached values higher than 1 for other elements, indicating the potential of Brassica napus to accumulate several heavy metals. Translocation Factor (TF) was reduced for $\mathrm{Co}, \mathrm{Cr}, \mathrm{Cd}, \mathrm{Cu}, \mathrm{Ni}, \mathrm{Zn}, \mathrm{Pb}$ and $\mathrm{As}$ after biochar addition indicating root accumulation of these metals. In all cases, biochar addition increased biomass production. Finally, the addition of BM450 increased GMea index indicating also an improvement on soil quality.
\end{abstract}

\section{Introduction}

Soils are important sinks for heavy metal released into the environment as a consequence of different anthropogenic 
activities. Mining and metallurgical plants, industrial effluents, urban activities and extensive use of pesticides, fertilizers or organic wastes, including sewage sludges in agriculture, have been considered the most important sources of metals in soils. Metals are non-biodegradable, persistent in soils for long periods and, depending on metal properties, concentration and chemical species, some of them can be toxic (Thornton, 1995) posing high risk to the environment and human health. In general, the main consequences of soil metal contamination comprise $\mathrm{pH}$ variations, high electrical conductivity, high salinity and pernicious effects in microbial activities and soil biodiversity (Kabata-Pendias and Pendias, 2001; Yang et al., 2012).

Traditionally, soil remediation techniques involve destructive practices such as soil excavation. However, there is an increasing interest in the development and use of low-cost, in-situ and ecological technologies, which allow not only soil decontamination but also the recovery of a fraction of the metals. Amongst them, phytoremediation techniques based on the use of some plants to remove contaminants from the environment (phytoextraction), to limit their mobility or bioavailability (phytostabilization) or to transform them into less harmful forms have been highlighted (Prasad, 2003; Vangronsveld et al., 2009). Phytoremediation is positively perceived by society and stakeholders. In addition, vegetation growth could prevent soil erosion and leaching of metals (Paz-Ferreiro et al., 2014; Prasad, 2003). However, there are some practical limitations associated to phytoremediation, mainly related to the long timespan required for soil remediation in highly contaminated areas. Concurrently, plant growth can be limited in areas with low pHs, high salinity or where the heavy metal concentration is unusually elevated. Most hyperaccumulator plants have slow growth rates limiting the amount of metals uptake. In order to improve soil properties and plant growth, several different materials have been endeavoured in order to assist phytoremediation. For example, the addition of organic amendments, including compost or biosolids has been attempted (Wang et al., 2012). However, these amendments can be associated to other concerns including odour issues and the potential release of organic contaminants. Much high-profile recent research has been devoted to the phytoremediation of metal polluted soils assisted by biochar amendment (Paz-Ferreiro et al., 2014; Houben et al., 2013; Lebrun et al., 2017, 2018; Li et al., 2018; Novak et al., 2018).

Biochar is a carbon-rich material obtained by pyrolysis of biomass that differs from charcoal, mainly used as fuel, as biochar act as carbon sinking in soils. Biochar addition to soil has been proved to improve some soil properties, leading to upgraded soil fertility (Paz-Ferreiro et al., 2012; Gascó et al., 2016; Méndez et al., 2012). In addition, it has been largely demonstrated that biochar addition to metal polluted soils decreases the bioavailability and leachability of metals such as $\mathrm{Cu}, \mathrm{Ni}, \mathrm{Cd}, \mathrm{Pb}, \mathrm{Cd}$ and $\mathrm{Zn}$ (Uchimiya et al., 2011; Park et al., 2012; Ryan et al., 2014; Rodríguez-Vila et al., 2015; Puga et al., 2016).

The choice of feedstock and the thermochemical conditions used to prepare biochar, greatly influence its properties and, consequently, its effect on soil properties. For example, organic wastes containing relatively high amounts of nutrients such as sewage sludges or animal manures lead to biochars with high nutrient content (Cely et al., 2015) that could be an excellent source of soil nutrients resulting in higher crop productivity. Surprisingly, most studies focused on biochar-assisted phytoremediation, have used plant-derived biochars (Lebrun et al., 2017, 2018; Li et al., 2018; Novak et al., 2018), which tend to have low amounts of nutrients. Considering that plant growth is one of the main constraints for phytoremediation programs, we found there is a strong potential to combine biochars rich in nutrients with phytoremediation techniques for the remediation of mining soils. The aim of the present work is to investigate the effects of two manure biochars prepared using different pyrolysis conditions combined with Brassica napus growth in the treatment of a mining soil from Riotinto mining area. Among many accumulating plant species suitable for phytoremediation brassicaceae have received considerable attention based on their capacity to uptake and accumulate different metals in large amounts, compared to other plant species (Prasad and Freitas, 2003). However, slow growth rate and relatively low yield pose constraints to their potential to be utilized for remediation (Paz-Ferreiro et al., 2014). Brassica napus has often been highlighted as a candidate for remediation in multicontaminated soils (Ehsan et al., 2014; Marchiol et al., 2004; Rossi et al., 2002). Brassica napus can accumulate significant amounts of Cd, Zn (Rossi et al., 2002), Pb (Shakoor et al., 2014) and Cu (Zaheer et al., 2015) in its tissues, and As in its roots (Gulz et al., 2005). Although Brassica napus is moderately tolerant to heavy metals (Marchiol et al., 2004), at high concentrations growth can be inhibited.

We propose that biochar from manure wastes can be used as soil amendment to improve phytoextraction by Brassica napus. However, there is considerable uncertainty concerning the effect of pyrolysis temperature used in biochar manufacture in plant growth. Therefore, the aim of this article is to study the effect of biochar, prepared from rabbit manure at two different temperatures, in the remediation, using Brassica napus, of a multicontaminated mining soil from Riotinto area. A focus of the study was on microbial biomass and soil enzymes as these biochemical properties provide an early indication of changes in soil quality (Paz-Ferreiro et al., 2009, 2012).

\section{Materials and methods}

\subsection{Selection and characterization of soils}

Soil (RIII) was selected from the mining area of Riotinto, Spain (Latitude: $37^{\circ} 43^{\prime} \mathrm{N}$, Longitude $6^{\circ} 36^{\prime} \mathrm{W}$, Altitude: $370 \mathrm{~m}$ ). Soil is nearby a pit copper mine reopened in 2016 and closed to an old mining dam.

The sample was air-dried, crushed and sieved through a $2 \mathrm{~mm}$ mesh prior to analysis. The $\mathrm{pH}$ and electrical conductivity (EC) were determined with a soil:water ratio of $1: 2.5\left(\mathrm{~g} \mathrm{~mL}^{-1}\right)$ using a Crison micro-pH 2000 and a Crison 222 conductivimeter, respectively. The effective cation exchange capacity (CEC) was determined using the standardized protocol ISO 23470 (2007) that is based on the centrifuge extraction with $0,0166 \mathrm{M}$ cobalt (III) hexamine chloride solution. The exchangeable $\mathrm{K}$ and $\mathrm{Na}$ was measured in the solution using a PerkinElmer AAnalyst 400 Atomic Absorption Spectrophotometer.

Oxidizable organic carbon (Cox) was determined by the Walkley-Black method (Nelson and Sommers, 1996) and the N was determined by Kjeldahl method (Bremner, 1996). Available phosphorous $(\mathrm{P})$ was determined using the Olsen method (Watanabe and Olsen, 1965). Metal content was determined using a PerkinElmer 2280 atomic absorption spectrophotometer after sample digestion with $3: 1(\mathrm{v} / \mathrm{v})$ concentrated $\mathrm{HCl} / \mathrm{HNO}_{3}$ following USEPA 3051a method (USEPA, 1997).

\subsection{Preparation and characterization of biochars}

The biomass feedstock, in our study manure waste (M), for preparation of biochars was collected in a rabbit farm located in the facilities of the Technical University of Madrid (Spain). Two biochars were prepared by pyrolysis of $\mathrm{M}$ at $450^{\circ} \mathrm{C}$ (BM450) and $600{ }^{\circ} \mathrm{C}$ (BM600). In both cases, the heating rate was $3^{\circ} \mathrm{C} \mathrm{min}-1$ and the residence time at final pyrolysis temperature was $1 \mathrm{~h}$. 
All samples were air-dried, crushed and sieved through a $2 \mathrm{~mm}$ mesh prior to analysis. Chemical properties of M, BM450 and BM600 (CEC; exchangeable K; Cox and P) and total heavy metal content were analysed using the same methods as described previously for soil characterization. $\mathrm{pH}$ and EC of biochars was determined in a sample:water ratio of $0.1: 25\left(\mathrm{~g} \cdot \mathrm{mL}^{-1}\right)$. Soluble organic matter (SOC) was extracted by addition of $10 \mathrm{~mL}$ water to $1 \mathrm{~g}$ (agitation $1 \mathrm{~h}$ ) and determined using Nelson and Sommers methodology (1996). Hg porosimetry was carried out using a Micromeritics AutoPore IV 9500 equipment. Finally, biochar nitrogen adsorption analysis was carried out at $77 \mathrm{~K}$ in a Micromeritics Tristar 3.00.

\subsection{Experimental design}

The soil (RIII) was amended with the two biochars (BM450 and $\mathrm{BM} 600)$ at a rate of $10 \%(\mathrm{w} / \mathrm{w})$ being named, respectively, RIII + BM450 and RIII + BM600. After that, all treatments were initially watered to $60 \%$ of field capacity and afterwards watered daily to account for moisture losses. Mixtures were introduced in 24 pots (volume: $500 \mathrm{~mL}$ ) and half of the mesocosm were planted with Brassica napus while in the remainder half the vegetative cover was absent. Then, pots were introduced in an incubator with light cycles every $12 \mathrm{~h}$ at a controlled temperature from 20 to $25^{\circ} \mathrm{C}$ for 60 days. Each treatment was replicated 3 times. After this time, shoots and roots were collected and dry weights were determined after drying at $80^{\circ} \mathrm{C}$ during $24 \mathrm{~h}$.

\subsection{Soil microbial biomass and soil enzyme activities}

Soil microbial biomass and dehydrogenase, phosphomonoesterase and $\beta$-glucosidase activities were determined in different treatments. Microbial biomass carbon was determined by the chloroform fumigation-extraction method (Vance et al., 1987). Dehydrogenase, phosphomonoesterase and $\beta$-glucosidase activities were determined following modifications of the original methods. While the amounts and concentrations of the substrates, buffers and other reagents were the same as in the original methods, different calibration curves were used for different treatments according to Paz-Ferreiro et al. (2009, 2012). Dehydrogenase activity was determined by a modification of the method as reported by Camiña et al. (1998). The results were expressed as $\mu \mathrm{mol}$ iodonitrotetrazolium formazan (INTF) $\mathrm{g}^{-1} \mathrm{~h}^{-1}$. Phosphomonoesterase and $\beta$-glucosidase were determined after incubating soils with a substrate containing a p-nitrophenyl moiety and then measuring the amount of p-nitrophenol released during enzymatic hydrolysis (Paz-Ferreiro et al., 2012). The activity of these two enzymes was expressed as $\mu \mathrm{mol}$ p-nitrophenol $\mathrm{g}^{-1} \mathrm{~h}^{-1}$.

Finally, the geometric mean (GMea) of the analysed enzyme activities was calculated for each sample as:

$$
\begin{aligned}
& \text { GMea }=(\text { phosphomonoesterase } \mathrm{x} \beta \\
& - \text { glucosidase } \mathrm{x} \text { dehydrogenase })^{1 / 3}
\end{aligned}
$$

This index offers an integrative information from variables that possess different units and range of variation and it has been established as an adequate index for estimating soil biochemical quality after the addition of different amendments, including biochar (Paz-Ferreiro et al., 2012).

\subsection{Metal content in soil and plants}

The extraction of total heavy metal content in plant shoots and roots were done as follows: $0.4 \mathrm{~g}$ of dried shoots and roots were put in a digestion tube and $3 \mathrm{~mL}$ of $\mathrm{HCl} 37 \%$ and $1 \mathrm{~mL}$ of $\mathrm{HNO}_{3} 69 \%$ were added. Then, digestion tubes were heated up from $60^{\circ} \mathrm{C}$ to $120^{\circ} \mathrm{C}$ for $1 \mathrm{~h}$. Following, heating was continued for another $2 \mathrm{~h}$ at $160^{\circ} \mathrm{C}$, and allowed to cool down to room temperature. Soil heavy metal content was extracted following USEPA 3051a method (USEPA, 1997).

Then, $\mathrm{Co}, \mathrm{Cd}, \mathrm{Cr}, \mathrm{Cu}, \mathrm{Ni}, \mathrm{Pb}, \mathrm{Zn}$, As and Se were determined using a Inductively Coupled Plasma Mass Spectrometry (ICP-MS) Perking Elmer.

The Bioaccumulation Factor (BAF) and Translocation Factor (TF) of Brassica napus were calculated to analyse the plant/soil relationships. BAF is the plant/soil element concentration ratio. Hyperaccumulators generally have BAF values higher than 1 (McGrath and Zhao, 2003). If $\mathrm{TF}>1$ the potential of a plant is to hyperaccumulate metals in the shoots (Baker and Brookes, 1989). $\mathrm{TF}<1$ the potential of a plant is to phytostabilize heavy metals in their roots. These two factors are calculated as follows:

$$
\begin{aligned}
& B A F=\frac{\text { Concentration of metal in shoots or roots }\left(\mathrm{mgkg}^{-1}\right)}{\text { Concentration of metal in soil }\left(\mathrm{mgkg}^{-1}\right)} \\
& \mathrm{TF}=\frac{\text { Concentration of metal in shoot }\left(\mathrm{mgkg}^{-1}\right)}{\text { Concentration of metal in root }\left(\mathrm{mgkg}^{-1}\right)}
\end{aligned}
$$

\subsection{Statistical analysis}

The significance of the differences among means was assessed by analysis of variance (ANOVA). Duncan's multiple range test $(p<0.05)$ was implemented using the Statgraphics Centurion XVI.I. software for the calculations.

\section{Results and discussion}

Table 1 shows the main properties of soil (RIII), manure waste (M) and two biochars (BM450 and BM600) and Table 2 the total heavy metal content of soil and biochars. The soil had significant amounts of $\mathrm{Cu}\left(231 \mathrm{mg} \mathrm{kg}^{-1}\right), \mathrm{Pb}\left(302 \mathrm{mg} \mathrm{kg}^{-1}\right)$. $\mathrm{Zn}\left(180 \mathrm{mg} \mathrm{kg}^{-1}\right)$, and $\mathrm{As}\left(180 \mathrm{mg} \mathrm{kg}^{-1}\right)$. The corresponding local regulatory limits for these elements in soils (Junta de Andalucía, 2015) are $595 \mathrm{mg} \mathrm{kg}^{-1}$ for $\mathrm{Cu}, 275 \mathrm{mg} \mathrm{kg}^{-1}$ for $\mathrm{Pb}, 10000 \mathrm{mg} \mathrm{kg}^{-1}$ for $\mathrm{Zn}$ and $40 \mathrm{mg} \mathrm{kg}^{-1}$ for As. The concentrations of these elements were in the range of critical soil total concentration (Kabata-Pendias and Pendias, 2001) (As: $20-50 \mathrm{mg} \mathrm{kg}^{-1}$; Pb: $100-400 \mathrm{mg} \mathrm{kg}^{-1}$; Cu: $60-125 \mathrm{mg} \mathrm{kg}^{-1}$; $\mathrm{Zn:} 70-140 \mathrm{mg} \mathrm{kg}^{-1}$ ) and above the levels indicated by regulations in other European jurisdictions or in other countries elsewhere (see for example Lu et al., 2018). These results are in agreement with the history of the area, as the selected soil is close to a wide copper mine area and these heavy metal concentrations disqualify the soil for agricultural, livestock or forestry activities due to the potential risk to human health and the environment.

The soil had a loam texture and presented an acidic $\mathrm{pH}$ according to its origin, the mining area of Riotinto (Spain). Soil CEC was very low $\left(3.6 \pm 0.6 \mathrm{cmol}_{(\mathrm{c})} / \mathrm{kg}\right)$ consistently with the low value of organic carbon $(0.22 \pm 0.10 \%)$.

The organic matter contained in the manure $(\mathrm{M})$ was transformed during pyrolysis due to the volatilization of light compounds and polymerization/condensation reactions. Consequently, the Cox and SOC contents decreased significantly with pyrolysis temperature. This was associated to decreases in the ratio $\mathrm{H} / \mathrm{C}$ (aromaticity index) and the increments of the ratio $\mathrm{O} / \mathrm{C}$ (functionalization index). These facts indicated that carbon structures of BM600 should be more stable than BM450 ones. These results were 
Table 1

Chemical properties and elemental analysis of soil, manure and biochars. Values are reported as means \pm standard deviation.

\begin{tabular}{|c|c|c|c|c|}
\hline & $\mathrm{R}-\mathrm{III}$ & M & BM450 & BM600 \\
\hline $\mathrm{pH}$ & $4.34 \pm 0.03 \mathrm{~d}^{\mathrm{a}}$ & $9.14 \pm 0.17 c$ & $10.59 \pm 0.06 b$ & $10.88 \pm 0.10$ \\
\hline $\mathrm{EC}\left(\mathrm{dS} \cdot \mathrm{m}^{-1}\right)$ & $0.09 \pm 0.01 c$ & $0.36 b \pm 0.08$ & $0.37 \pm 0.04 b$ & $0.46 \pm 0.08 a$ \\
\hline $\mathrm{CEC}\left(\mathrm{cmol} \cdot \mathrm{kg}^{-1}\right)$ & $3.6 \pm 0.6 d$ & $111 \pm 1 c$ & $148 \pm 2 \mathrm{a}$ & $132 \pm 5 b$ \\
\hline $\operatorname{Cox}(\%)$ & $1.34 \mathrm{c} \pm 0.03 \mathrm{~d}$ & $20.59 \pm 0.18 a$ & $11.34 \pm 0.18 b$ & $4.99 \pm 1.45 c$ \\
\hline SOC (\%) & $0.22 \pm 0.10 b$ & $0.45 \pm 0.01 a$ & $0.15 \pm 0.01 c$ & $0.04 \pm 0.02 d$ \\
\hline $\mathrm{P}\left(\mathrm{mg} \cdot \mathrm{kg}^{-1}\right)$ & $1944 \pm 219 b$ & $2632 \pm 127 a$ & $939 \pm 21 c$ & $752 \pm 48 d$ \\
\hline $\mathrm{K}\left(\mathrm{kg} \cdot \mathrm{kg}^{-1}\right)$ & $0.1 \pm 0.01 c$ & $5.6 \pm 0.5 b$ & $10.9 \pm 0.2 a$ & $11.6 \pm 0.3 a$ \\
\hline Texture & Loam & - & - & - \\
\hline C (\%) & - & 36.47 & 28.52 & 24.99 \\
\hline $\mathrm{H}(\%)$ & - & 4.93 & 1.72 & 1.33 \\
\hline $\mathrm{N}(\%)$ & $0.09^{\mathrm{b}}$ & 3.19 & 1.47 & 0.38 \\
\hline $\mathrm{O}(\%)$ & - & 7.89 & 12.58 & 14.11 \\
\hline $\mathrm{S}(\%)$ & - & 0.62 & 0.37 & 0.36 \\
\hline $\mathrm{H} / \mathrm{C}$ ratio & - & 1.62 & 0.73 & 0.64 \\
\hline $\mathrm{O} / \mathrm{C}$ ratio & - & 0.16 & 0.33 & 0.42 \\
\hline BET surface area $\left(\mathrm{m}^{2} \cdot \mathrm{g}^{-1}\right)$ & - & - & 5.6767 & 35.9662 \\
\hline Micropore area $\left(\mathrm{m}^{2} \cdot \mathrm{g}^{-1}\right)$ & - & - & 1.7959 & 4.2019 \\
\hline Adsorption average pore width $(\AA)$ & - & - & 166.23 & 104.81 \\
\hline Vmicro $\left(\mathrm{cm}^{3} \cdot \mathrm{g}^{-1}\right)$ & - & - & 0.0236 & 0.0942 \\
\hline Vmeso $\left(\mathrm{cm}^{3} \cdot \mathrm{g}^{-1}\right)$ & - & - & 0.0398 & 0.0738 \\
\hline Vmacro $\left(\mathrm{cm}^{3} \cdot \mathrm{g}^{-1}\right)$ & - & - & 1.6470 & 2.1239 \\
\hline Porosity (\%) & - & - & 75.25 & 72.72 \\
\hline
\end{tabular}

${ }^{\text {a }}$ Values are reported as means \pm standard deviation. Values in row followed by the same letter are not significantly different $(\mathrm{P}=0.05)$ using the Duncan test.

b For soil, $\mathrm{N}$ was determined by Kjeldahl method.

Table 2

Total heavy metal content in soil and biochars.

\begin{tabular}{llll}
\hline & R III & BM450 & BM600 \\
\hline Co total $\left(\mathrm{mg} \cdot \mathrm{kg}^{-1}\right)$ & $3.9 \pm 0.1 \mathrm{a}$ & $2.3 \pm 0.4 \mathrm{~b}$ & $3.0 \pm 0.3 \mathrm{~b}$ \\
Cu total $\left(\mathrm{mg} \cdot \mathrm{kg}^{-1}\right)$ & $231 \pm 1 \mathrm{a}$ & $74 \pm 5 \mathrm{~b}$ & $61 \pm 2 \mathrm{c}$ \\
$\mathrm{Cd}$ total $\left(\mathrm{mg} \cdot \mathrm{kg}^{-1}\right)$ & $0.06 \pm 0.01 \mathrm{~b}$ & $0.36 \pm 0.02 \mathrm{a}$ & $0.34 \pm 0.04 \mathrm{a}$ \\
Cr total $\left(\mathrm{mg} \cdot \mathrm{kg}^{-1}\right)$ & $5.8 \pm 0.5 \mathrm{~b}$ & $8.2 \pm 0.8 \mathrm{a}$ & $8.3 \pm 0.7 \mathrm{a}$ \\
Se total $\left(\mathrm{mg} \cdot \mathrm{kg}^{-1}\right)$ & $3.4 \pm 0.1 \mathrm{a}$ & $0.19 \pm 0.02 \mathrm{~b}$ & $0.15 \pm 0.03 \mathrm{~b}$ \\
Pb total $\left(\mathrm{mg} \cdot \mathrm{kg}^{-1}\right)$ & $302 \pm 32 \mathrm{a}$ & $10 \pm 1 \mathrm{~b}$ & $11 \pm 2 \mathrm{~b}$ \\
Ni total $\left(\mathrm{mg} \cdot \mathrm{kg}^{-1}\right)$ & $1.8 \pm 0.1 \mathrm{c}$ & $6.7 \pm 0.2 \mathrm{~b}$ & $7.9 \pm 0.2 \mathrm{a}$ \\
Zn total $\left(\mathrm{mg} \cdot \mathrm{kg}^{-1}\right)$ & $180 \pm 9 \mathrm{c}$ & $870 \pm 15 \mathrm{a}$ & $753 \pm 7 \mathrm{~b}$ \\
As total $\left(\mathrm{mg} \cdot \mathrm{kg}^{-1}\right)$ & $180 \pm 5 \mathrm{a}$ & $2.15 \pm 0.15 \mathrm{~b}$ & $2.21 \pm 0.58 \mathrm{~b}$ \\
\hline
\end{tabular}

a Values are reported as means \pm standard deviation. Values in row followed by the same letter are not significantly different $(P=0.05)$ using the Duncan test.

in agreement to previous researchers who established that biochar stability increases with pyrolysis temperatures (Cely et al., 2015; Méndez et al., 2013). With respect to other agronomic properties, BM450 showed higher P, CEC and N content than BM600, while biochar BM600 showed higher BET surface area and higher values of micropore volume (Vmicro), macropore volume (Vmacro) and mesopore volume (Vmeso) than BM450. It is well known that the porosity development of biochar is promoted by thermal treatment at higher temperatures (Bagreev et al., 2001; Méndez et al., 2013). These parameters jointly with CEC can have a great influence in heavy metal chemisorption in the biochar surface.

Pyrolysis treatment of $\mathrm{M}$ increased the $\mathrm{pH}$ more to a value over 10 , with the highest $\mathrm{pH}$ corresponding to biochar prepared at the highest temperature (BM600). The EC increased in the BM600 biochar, but not in the B450 biochar, due to ash concentration after pyrolysis process.

Biochar addition increased soil $\mathrm{pH}$ from 4.32 to more than 8.10 (Table 3 ) which can have consequences in heavy metal mobility as heavy metals are more mobile, in general, under acidic conditions (Alloway, 1995). After the addition of the two biochars, there is a reduction in the content of $\mathrm{Cu}, \mathrm{Se}, \mathrm{Pb}$ and $\mathrm{As}$ and an increment in the $\mathrm{Zn}$ and Ni content according to the initial heavy metal biochar contents (see data of Table 2 and without Brassica napus in Table 3). The sowing of Brassica napus, with and without biochar, reduced the content of the $\mathrm{Co}, \mathrm{Cu}, \mathrm{Cr}, \mathrm{Se}, \mathrm{Pb}$ and As with respect to the untreated soil (RIII). There was no effect with respect to Cd content and the $\mathrm{Zn}$ and $\mathrm{Ni}$ soil concentrations were only reduced when control soil (RIII) with and without Brassica napus were compared. In this last case, it must be taken account that the content in $\mathrm{Ni}$ and $\mathrm{Zn}$ was slightly increased after biochar addition. Indeed, Brassica napus reduced the $\mathrm{Ni}$ content in the soil treated with biochar BM600 (RIII + BM600).

In treatments combining Brassica napus growth with biochar addition, noteworthy effects were observed. Combining BM450 with Brassica napus significantly decreased the amount of $\mathrm{Cu}, \mathrm{Pb}$ and As in the mining soil RIII, whereas addition of BM600 only reduced the amount of $\mathrm{As}, \mathrm{Cu}$ and Se but no significant differences were observed in $\mathrm{Pb}$ content. Overall, the addition of biochar had a positive effect on the remediation of Riotinto mining soil by Brassica napus.

Table 4 shows the variation on dry biomass production of Brassica napus with respect to RIII after biochar addition (RIII + BM450 and RIII + BM600). It could be observed that biochar addition significantly increased the weight of shoots and roots. Roughly, BM600 resulted in a 5.8 fold increase in biomass shoot yield and 2 fold increases in roots, while BM450 resulted in a 12 fold increase in biomass shoots productivity and 2.8 fold in roots. Biochar is commonly reported in previous researches to improve plant growth probably due to increases in nutrient content, higher cation exchange capacities and improvement on biological properties and pH (Paz-Ferreiro et al., 2014). In this research, biochar BM450 showed the highest CEC, Cox, P and N content (Table 1).

Table 5 shows the metal contents in shoots and roots of Brassica napus grown in RIII, RIII + BM450 and RIII + BM600. The highest metal concentrations in shoots were observed for $\mathrm{Cu}\left(109 \mathrm{mg} \mathrm{kg}^{-1}\right)$ and $\mathrm{Zn}\left(373 \mathrm{mg} \mathrm{kg}^{-1}\right)$ in the soil without biochars (RIII). After addition of biochars, shoot concentration of $\mathrm{Co}, \mathrm{Cd}, \mathrm{Cr}, \mathrm{Cu}, \mathrm{Ni}, \mathrm{Zn}, \mathrm{Pb}$ and As significantly decreased and only Se shoot concentration was higher in the presence of biochar. The lower metal concentrations after biochar addition (RIII + BM450 and RIII + B600 treatment) can be associated to a dilution effect, as a consequence of higher shoot production (Table 4). With respect to metal root concentrations, the highest concentrations were found for $\mathrm{Cu}\left(269 \mathrm{mg} \mathrm{kg}^{-1}\right)$ in the 
Table 3

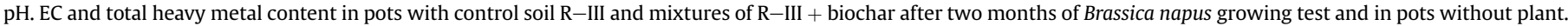

\begin{tabular}{|c|c|c|c|c|c|c|}
\hline & \multicolumn{3}{|c|}{ Without Brassica napus } & \multicolumn{3}{|c|}{ With Brassica napus } \\
\hline & R III & R III + BM450 & R III + BM600 & R III & R III + BM450 & R III + BM600 \\
\hline $\mathrm{pH}$ & $4.32 \pm 0.13 c^{a}$ & $8.16 \pm 0.02 b$ & $8.30 \pm 0.04 b$ & $4.22 \pm 0.06 c$ & $8.20 \pm 0.11 b$ & $8.55 \pm 0.02 a$ \\
\hline EC $\left(\mathrm{dS} \cdot \mathrm{m}^{-1}\right)(10: 25 \mathrm{p} / \mathrm{v})$ & $0.08 \pm 0.01 c$ & $1.98 \pm 0.03 b$ & $2.26 \pm 0.13 a$ & $0.09 \pm 0.01 \mathrm{c}$ & $2.34 \pm 0.03 a$ & $2.27 \pm 0.14 a$ \\
\hline Co total $\left(\mathrm{mg} \cdot \mathrm{kg}^{-1}\right)$ & $3.9 \pm 0.1 \mathrm{a}$ & $4.1 \pm 0.4 a$ & $3.8 \pm 0.3 a$ & $2.9 \pm 0.12 c$ & $2.6 \pm 0.03 c$ & $2.6 \pm 0.04 c$ \\
\hline $\mathrm{Cu}$ total $\left(\mathrm{mg} \cdot \mathbf{k g}^{-1}\right)$ & $231 \pm 15 a$ & $186 \pm 21 b$ & $170 \pm 16 c$ & $188 \pm 10 b$ & $156 \pm 3 c d$ & $151 \pm 5 d$ \\
\hline Cd total $\left(\mathrm{mg} \cdot \mathbf{k g}^{-1}\right)$ & $0.07 \pm 0.01 b$ & $0.11 \pm 0.01 \mathrm{ab}$ & $0.10 \pm 0.04 \mathrm{ab}$ & $0.06 \pm 0.01 b$ & $0.12 \pm 0.06 a$ & $0.09 \pm 0.02 \mathrm{ab}$ \\
\hline $\mathrm{Cr}$ total $\left(\mathrm{mg} \cdot \mathrm{kg}^{-1}\right)$ & $5.8 \pm 0.5 a$ & $5.9 \pm 0.6 a$ & $4.7 \pm 0.4 b$ & $4.4 \pm 0.5 b$ & $4.3 \pm 0.4 b$ & $3.5 \pm 0.1 \mathrm{c}$ \\
\hline $\mathrm{Se}_{\text {total }}\left(\mathrm{mg} \cdot \mathbf{k g}^{-1}\right)$ & $3.4 \pm 0.10 a$ & $2.9 \pm 0.1 b$ & $2.6 \pm 0.1 \mathrm{c}$ & $2.3 \pm 0.2 \mathrm{~d}$ & $2.2 \pm 0.1 \mathrm{~d}$ & $1.9 \pm 0.1 \mathrm{e}$ \\
\hline $\mathbf{P b}$ total $\left(\mathbf{m g} \cdot \mathbf{k g}^{-1}\right)$ & $302 \pm 22 a$ & $274 \pm 18 a b$ & $255 \pm 15 b$ & $212 \pm 13 c$ & $186 \pm 24 c$ & $210 \pm 21 c$ \\
\hline $\mathrm{Ni}$ total $\left(\mathrm{mg} \cdot \mathbf{k g}^{-1}\right)$ & $1.8 \pm 0.1 b$ & $2.8 \pm 0.1 \mathrm{a}$ & $2.2 \pm 0.2 b$ & $1.4 \pm 0.3 c$ & $2.1 \pm 0.1 b$ & $2.0 \pm 0.3 b$ \\
\hline $\mathrm{Zn}$ total $\left(\mathrm{mg} \cdot \mathrm{kg}^{-1}\right)$ & $180_{ \pm} 9 \mathrm{~b}$ & $262 \pm 23 a$ & $258 \pm 10 a$ & $133 \pm 11 c$ & $204 \pm 18 b$ & $200 \pm 19 b$ \\
\hline As total $\left(\mathrm{mg} \cdot \mathrm{kg}^{-1}\right)$ & $180 \pm 5 a$ & $145 \pm 6 b$ & $138 \pm 10 b$ & $137 \pm 10 b$ & $116 \pm 6 c$ & $108 \pm 6 c$ \\
\hline
\end{tabular}

${ }^{\text {a }}$ Values are reported as means \pm standard deviation. Values in row followed by the same letter are not significantly different $(\mathrm{P}=0.05)$ using the Duncan test.

Table 4

Variation on biomass production of Brassica napus with respect to control after biochar addition.

\begin{tabular}{lll}
\hline & Shoots & Roots \\
\hline R III + BM 450/3 & $12.2 \pm 0.38 \mathrm{a}^{\mathrm{a}}$ & $2.8 \pm 0.21 \mathrm{a}$ \\
R III + BM 600/3 & $5.8 \pm 0.20 \mathrm{~b}$ & $2.0 \pm 0.25 \mathrm{~b}$ \\
\hline
\end{tabular}

${ }^{\text {a }}$ Values are reported as means \pm standard deviation. Values in row followed by the same letter are not significantly different $(\mathrm{P}=0.05)$ using the Duncan test. Variation is calculated with respect to control.

untreated soil, RIII. Combination of biochar and Brassica napus reduced the concentration of $\mathrm{Co}, \mathrm{Cd}, \mathrm{Cr}, \mathrm{Cu}$ in the shoots but significantly increased the concentration of $\mathrm{Zn}$ and As. This effect was produced in spite of higher root weights following biochar addition of both biochars. This indicates that BM450 and BM600 application could increase the stabilization of $\mathrm{Zn}$ and As. There were not significant differences for both $\mathrm{Ni}$ and $\mathrm{Pb}$ content in the roots. Specifically, the increment of As root concentration after biochar addition ranged from 94\% (BM450) to 39\% (BM600) although the shoot concentration was higher in the unamended soil. In general, there is an increase in As toxicity effects on plants in soils with $\mathrm{pH}$ below 5 due to As species becoming more soluble (Alloway, 1995) although the uptake of As by plants can be increased in calcareous loam soils ( $\mathrm{pH}>8$ ) (Campbell et al., 1997). Symptoms of As toxicity can be visible in plants growing in light soils with As concentration of $100 \mathrm{ppm}$ (Woolson et al., 1973). Symptoms of As toxicity include leaf wilting and violet coloration combined with growth reduction (Kabata-Pendias and Pendias, 2001 ) as it is shown in Fig. 1. We observed these symptoms in all the treatments but especially in unamended soil, and it can be the reason for the low growth of Brassica napus at the end of the experiment. Indeed, As concentration was above the range $5-20 \mathrm{mg} \mathrm{kg}^{-1}$ which constitutes the lower threshold for toxicity effects. As was previously established, higher values of As usually result in reduced yields (McNichol and Beckett, 1985). Also, the plant concentration of $\mathrm{Cr}, \mathrm{Cu}, \mathrm{Zn}$ and $\mathrm{Pb}$ were in critical levels

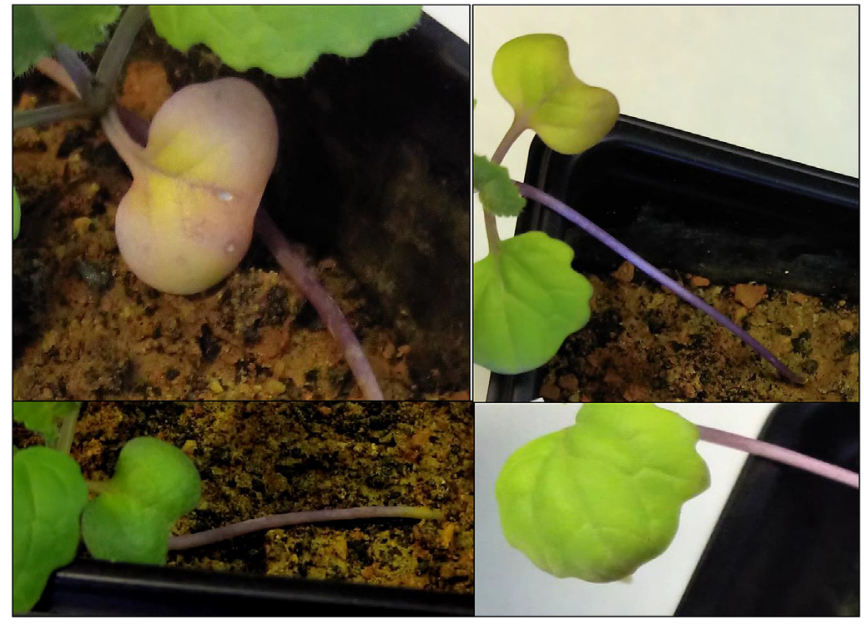

Fig. 1. Symptoms of As toxicity observed in Brassica napus during the experiment.

according to Kabata-Pendias and Pendias (2001), this is $\mathrm{Cr}$ : 5-30 $\mathrm{mg} \mathrm{kg}^{-1}$, Cu: $20-100 \mathrm{mg} \mathrm{kg}^{-1}, \mathrm{Zn}: 100-400 \mathrm{mg} \mathrm{kg}^{-1}, \mathrm{~Pb}$ : $30-300 \mathrm{mg} \mathrm{kg}^{-1}$, and therefore it can contribute to the reduction on plant growth.

Table 6 shows bioaccumulation factor in shoots (BAFs) and roots (BAFr) and translocation factor (TF) of analysed metals on Brassica napus in RIII, RIII + BM450 and RIII + BM600 treatments. BAFs in the control soil (RIII) is higher than 1.0 for $\mathrm{Co}, \mathrm{Cr}, \mathrm{Ni}, \mathrm{Cd}$ and $\mathrm{Zn}$ indicating that Brassica napus is an accumulator plant in shoots for these metals. With respect to the accumulation in the roots, BAFr in the control soil was higher than 1 for $\mathrm{Co}, \mathrm{Cd}, \mathrm{Cr}, \mathrm{Cu}, \mathrm{Ni}$ and $\mathrm{Se}$ indicating an accumulation on root tissues. These results are in accordance to Park et al. (2012) who concluded that Brassica napus can be used for the treatment of heavy metal contaminated soils and that the plant uptake was related with the phyto-available heavy metal fraction in soils.

Table 5

Total heavy metal content in roots and aerial part of Brassica napus in control R-III and mixtures of R-III + biochar pots after two months.

\begin{tabular}{|c|c|c|c|c|c|c|c|c|c|c|}
\hline & & Co $\left(\mathrm{mg} \cdot \mathrm{kg}^{-1}\right)$ & Cd (mg. $\left.\mathbf{k g}^{-1}\right)$ & $\operatorname{Cr}\left(\mathbf{m g} \cdot \mathbf{k g}^{-1}\right)$ & $\mathrm{Cu}\left(\mathbf{m g} \cdot \mathbf{k g}^{-1}\right)$ & $\mathrm{Ni}\left(\mathrm{mg} \cdot \mathrm{kg}^{-1}\right)$ & $\mathrm{Zn}\left(\mathbf{m g} \cdot \mathbf{k g}^{-1}\right)$ & $\mathrm{Pb}\left(\mathrm{mg} \cdot \mathrm{kg}^{-1}\right)$ & As (mg. $\left.\mathbf{k g}^{-1}\right)$ & $\mathrm{Se}\left(\mathrm{mg} \cdot \mathrm{kg}^{-1}\right)$ \\
\hline \multirow[t]{3}{*}{ Shoots } & R III & $3.5 \pm 0.2 \mathrm{a}^{\mathrm{a}}$ & $0.97 \pm 0.08 a$ & $6.7 \pm 0.8 a$ & $109 \pm 5 c$ & $3.4 \pm 0.2 \mathrm{a}$ & $373 \pm 17 a$ & $63 \pm 4 c$ & $22 \pm 1 a$ & $2.2 \pm 0.1 \mathrm{~d}$ \\
\hline & R III + BM450 & $0.2 \pm 0.06 c$ & $0.11 \pm 0.05 \mathrm{~cd}$ & $2.4 \pm 0.7 c$ & $19 \pm 3 d$ & $1.1 \pm 0.1 b$ & $100 \pm 15 c$ & $6.2 \pm 0.3 d$ & $6 \pm 1 d$ & $3.6 \pm 0.3 b$ \\
\hline & R III + BM600 & $0.2 \pm 0.01 c$ & $0.07 \pm 0.02 d$ & $2.3 \pm 0.8 c$ & $26 \pm 5 d$ & $1.0 \pm 0.2 b$ & $52 \pm 5 d$ & $8.6 \pm 1.6 d$ & $15 \pm 1 c$ & $4.2 \pm 0.1 \mathrm{a}$ \\
\hline \multirow[t]{3}{*}{ Roots } & R III & $3.3 \pm 0.1 \mathrm{a}$ & $0.70 \pm 0.15 b$ & $5.7 \pm 0.2 \mathrm{a}$ & $269 \pm 7 a$ & $2.9 \pm 0.1 \mathrm{a}$ & $125 \pm 3 c$ & $203 \pm 23 b$ & $67 \pm 2 d$ & $2.9 \pm 0.1 c$ \\
\hline & R III + BM450 & $2.3 \pm 0.5 b$ & $0.19 \pm 0.09 c$ & $3.6 \pm 0.4 b c$ & $180 \pm 18 b$ & $3.0 \pm 0.3 a$ & $191 \pm 13 b$ & $184 \pm 24 b$ & $130 \pm 12 \mathrm{e}$ & $2.5 \pm 0.3 c d$ \\
\hline & R III + BM600 & $1.8 \pm 0.3 b$ & $0.19 \pm 0.06 c$ & $4.5 \pm 0.4 b$ & $166 \pm 6 b$ & $2.5 \pm 0.2 \mathrm{a}$ & $178 \pm 12 b$ & $152 \pm 31 b$ & $93 \pm 10 f$ & $2.9 \pm 0.1 c$ \\
\hline
\end{tabular}

${ }^{a}$ Values are reported as means \pm standard deviation. Values in row followed by the same letter are not significantly different $(\mathrm{P}=0.05)$ using the Duncan test. 
Table 6

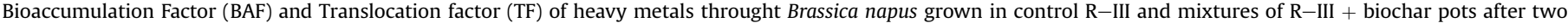
months.

\begin{tabular}{|c|c|c|c|c|c|c|c|c|c|c|}
\hline & & Co & $\mathrm{Cd}$ & $\mathrm{Cr}$ & $\mathrm{Cu}$ & $\mathrm{Ni}$ & $\mathrm{Zn}$ & $\mathrm{Pb}$ & As & Se \\
\hline \multirow[t]{3}{*}{ BAF in shoots } & R III & $1.31 \mathrm{a}^{\mathrm{a}}$ & $15.16 a$ & $1.54 a$ & $0.58 \mathrm{a}$ & $2.41 \mathrm{a}$ & $2.79 a$ & $0.02 \mathrm{a}$ & $0.16 a$ & $0.93 c$ \\
\hline & R III + BM450 & $0.09 \mathrm{~b}$ & $0.92 b$ & $0.54 \mathrm{~b}$ & $0.12 b$ & $0.51 b$ & $0.49 \mathrm{~b}$ & $0.03 b$ & $0.05 \mathrm{~b}$ & $1.65 b$ \\
\hline & R III + BM600 & $0.09 b$ & $0.86 \mathrm{~b}$ & $0.64 b$ & $0.17 b$ & $0.47 b$ & $0.26 b$ & $0.04 \mathrm{~b}$ & $0.14 b$ & $2.17 \mathrm{a}$ \\
\hline \multirow[t]{3}{*}{ BAF in roots } & R III & $1.15 a$ & $10.86 a$ & $1.31 \mathrm{a}$ & $1.43 a$ & $2.02 \mathrm{a}$ & $0.94 a$ & $0.96 a$ & $0.49 c$ & $1.26 \mathrm{ab}$ \\
\hline & R III + BM450 & $0.87 \mathrm{ab}$ & $1.99 b$ & $0.84 \mathrm{~b}$ & $1.14 \mathrm{a}$ & $1.43 a$ & $0.93 a$ & $0.67 a$ & $1.13 a$ & $1.13 b$ \\
\hline & R III + BM600 & $0.70 \mathrm{~b}$ & $2.21 \mathrm{~b}$ & $1.29 \mathrm{a}$ & $1.10 \mathrm{a}$ & $1.22 \mathrm{a}$ & $0.89 a$ & $0.72 \mathrm{a}$ & $0.86 \mathrm{~b}$ & $1.50 \mathrm{a}$ \\
\hline \multirow[t]{3}{*}{ TF } & R III & $1.07 \mathrm{a}$ & $1.42 \mathrm{a}$ & $1.18 \mathrm{a}$ & $0.41 \mathrm{a}$ & $1.19 a$ & $2.98 a$ & $0.31 \mathrm{a}$ & $0.32 \mathrm{a}$ & $0.74 \mathrm{~b}$ \\
\hline & R III + BM450 & $0.11 b$ & $0.61 b$ & $0.67 b$ & $0.11 \mathrm{~b}$ & $0.37 b$ & $0.55 b$ & $0.04 \mathrm{~b}$ & $0.05 c$ & $1.48 \mathrm{a}$ \\
\hline & R III + BM600 & $0.13 b$ & $0.39 b$ & $0.54 b$ & $0.15 b$ & $0.51 b$ & $0.32 b$ & $0.06 \mathrm{~b}$ & $0.16 b$ & $1.45 \mathrm{a}$ \\
\hline
\end{tabular}

${ }^{\mathrm{a}}$ Values for each metal and each index followed by the same letter are not significantly different $(\mathrm{P}=0.05)$ using the Duncan test.

After biochar addition, the BAFs decreased for $\mathrm{Co}, \mathrm{Cr}, \mathrm{Cd}, \mathrm{Cu}, \mathrm{Ni}$, $\mathrm{Zn}$ and As and only accumulated Se while the BAFr showed as the addition of biochar only increased significantly the accumulation of As. The general reduction of the metal concentration in the plant after biochar addition, except in some cases, can be due to different factors, including more elevated $\mathrm{pH}$ or CEC after biochar application (Paz-Ferreiro et al., 2014) that reduced the bioavailability of the metals (Méndez et al., 2012) and to dilution effect, as a consequence of higher plant biomass production. These results are in accordance to Beesley and Marmiroli (2011) who observed that biochar was effective reducing the solubility of metals as $\mathrm{Cd}$ and $\mathrm{Zn}$ being sorption one of the mechanisms by which these metals were retained.

Translocation factor (TF), as mentioned before, indicates the potential of a species to hyperaccumulate metals in the shoots $(\mathrm{TF}>1)$ or to phytostabilize heavy metals in their roots $(\mathrm{TF}<1)$. In our case, TF values indicated that Brassica napus accumulated Co, $\mathrm{Cd}, \mathrm{Cr}, \mathrm{Ni}$, and $\mathrm{Zn}, \mathrm{Pb}$ in shoots while $\mathrm{Cu}, \mathrm{Pb}$, As and Se were mainly accumulated in the roots. The addition of biochar significantly reduced the TF for all metals indicating that biochars stimulated the root accumulation of all metals $(\mathrm{TF}<1)$ except for Se.

The addition of biochar produced an increment on plant yield due to the improvement of soil nutrient content, organic carbon level and increment of the $\mathrm{pH}$ after biochar addition (Paz-Ferreiro
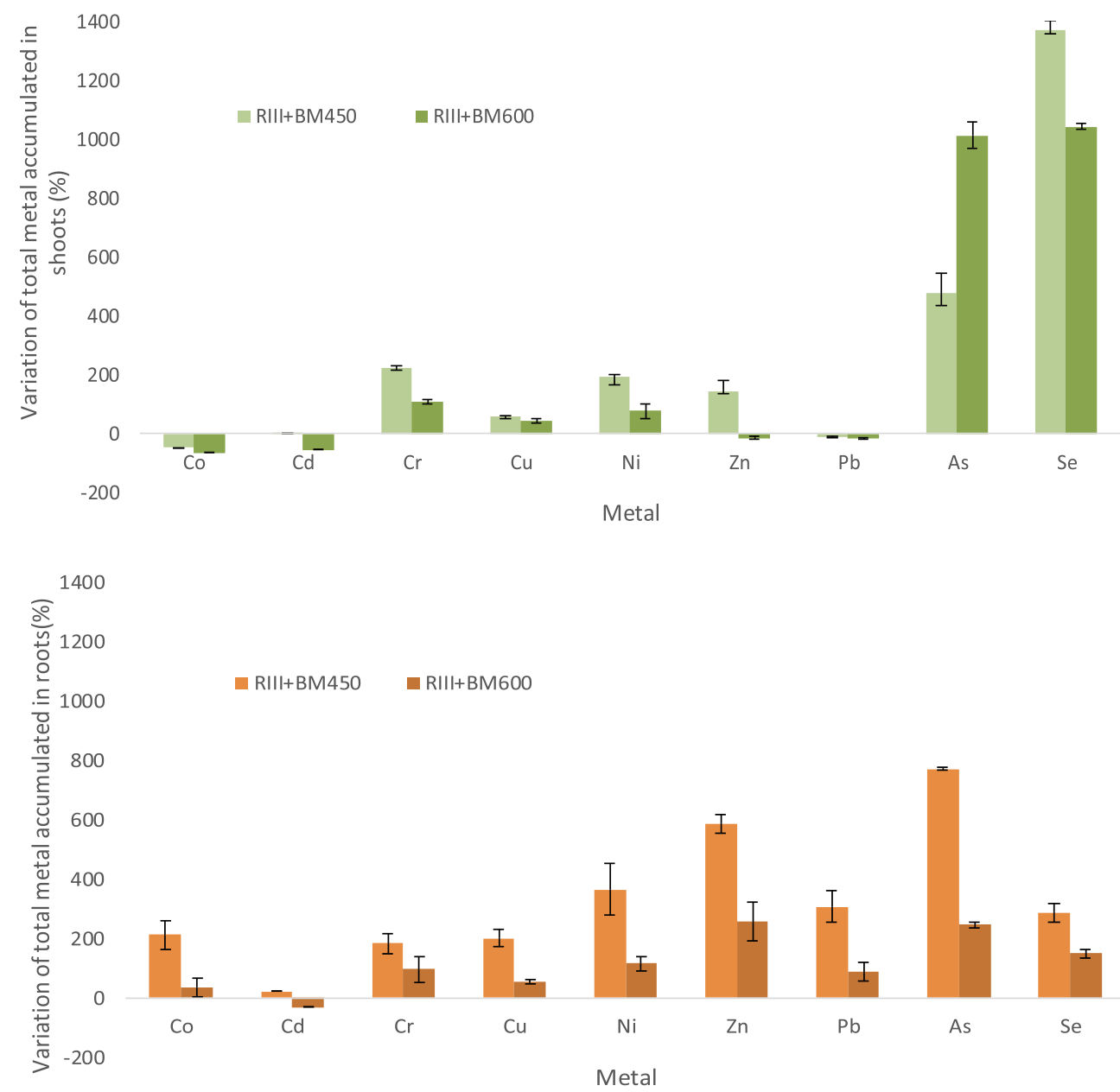

Fig. 2. Variation of the total metal uptaken by Brassica napus with respect to control soil (RIII). Values are reported as means \pm standard deviation. 


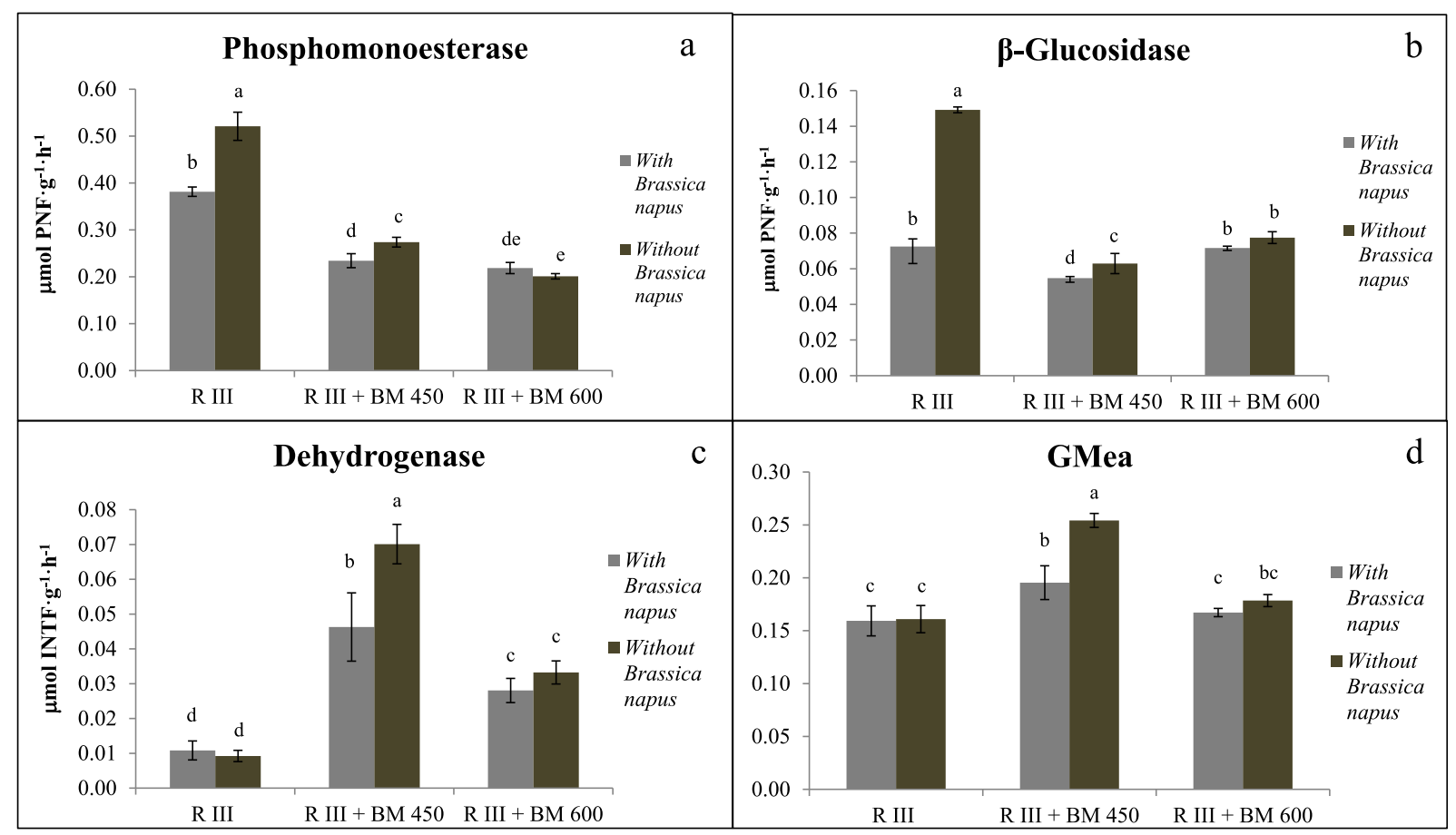

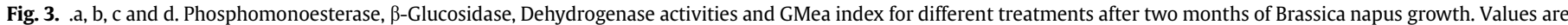
reported as means \pm standard deviation. Means with common letter are not significantly different $(p>0.05)$ using the Duncan test.

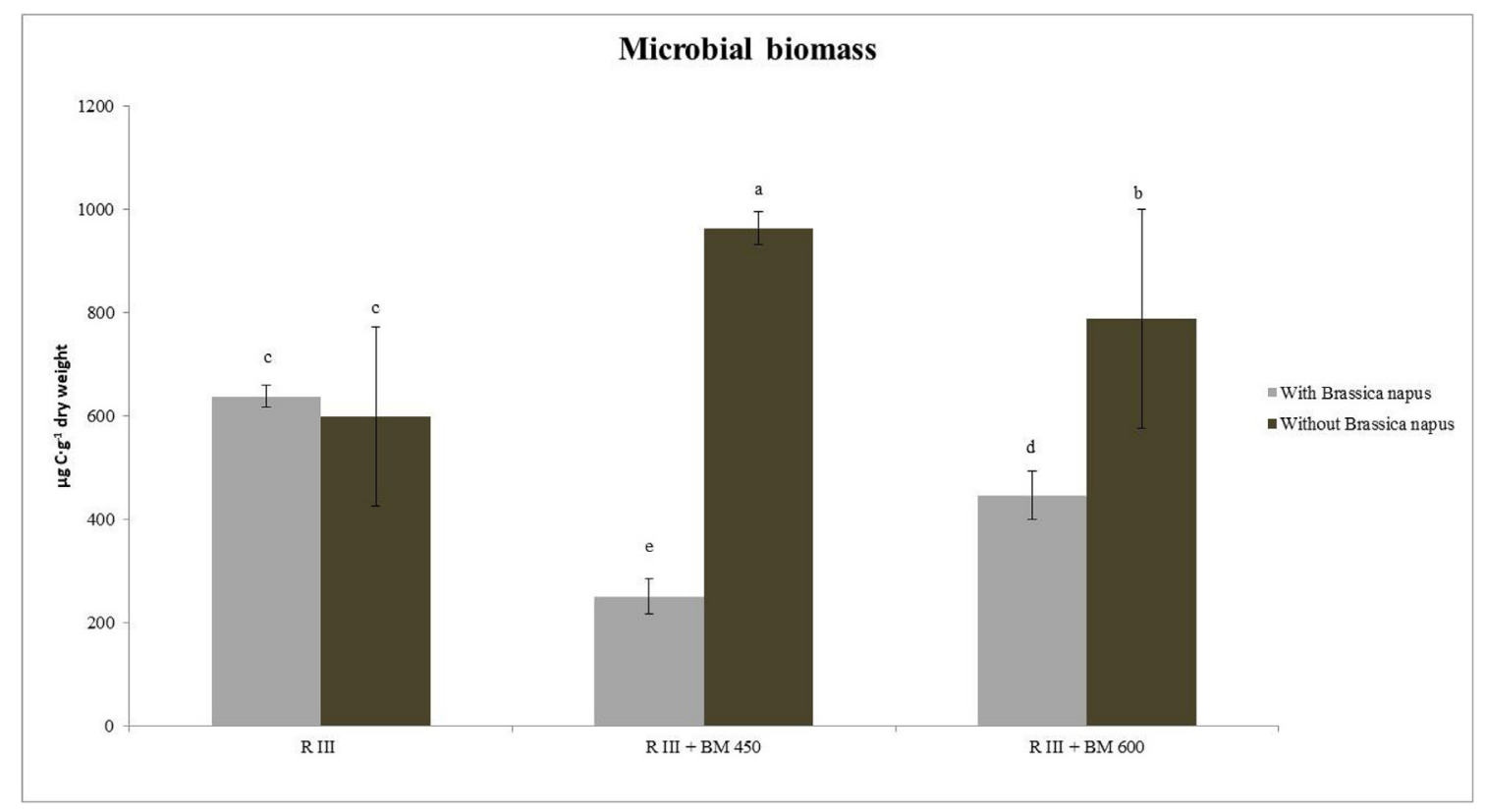

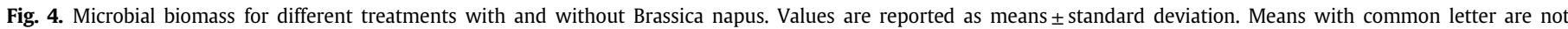
significantly different $(\mathrm{p}>0.05)$ using Duncan test.

et al., 2014) that can compensate the reduction of the metal concentration in the plant. Fig. 2 shows the variation of the extracted total metals (\%) by Brassica napus with respect to the unamended soil (RIII). The sequences for the shoots were

RIII + BM450 treatment: $\mathrm{Co}(-49 \%)<\mathrm{Pb}(-11 \%)<\mathrm{Cd}(2 \%)<\mathrm{Cu}$ $(57 \%)<\mathrm{Zn}(141 \%)<\mathrm{Ni}(191 \%)<\mathrm{Cr}(222 \%)<\mathrm{As}(478 \%)<\mathrm{Se}(1373 \%)$

RIII + BM600 treatment: Co $(-66 \%)<\mathrm{Cd}(-57 \%)<\mathrm{Pb}$ $(-18 \%)<\mathrm{Zn}(-16 \%)<\mathrm{Cu}(43 \%)<\mathrm{Ni}(76 \%)<\mathrm{Cr}(106 \%)<\mathrm{As}$ $(1015 \%)<$ Se $(1045 \%)$ and for the roots

RIII + BM450 treatment: Cd $(22 \%)<\mathrm{Cr}(184 \%)<\mathrm{Cu}(201 \%)<\mathrm{Co}$ $(214 \%)<\mathrm{Se}(288 \%)<\mathrm{Pb}(308 \%)<\mathrm{Ni}(366 \%)<\mathrm{Zn}(588 \%)<\mathrm{As}(773 \%)$ RIII + BM600 treatment: Cd $(-32 \%)<\mathrm{Co}(36 \%)<\mathrm{Cu}(54 \%)<\mathrm{Pb}$ $(87 \%)<\mathrm{Cr}(97 \%)<\mathrm{Ni}(116 \%)<\mathrm{Se}(150 \%)<\operatorname{As}(247 \%)<\mathrm{Zn}(257 \%)$

There was an increment in the total heavy metal accumulation in the shoots of $\mathrm{Cr}, \mathrm{Cu}, \mathrm{Ni}, \mathrm{Zn}$, As and $\mathrm{Se}$ and of $\mathrm{Co}, \mathrm{Cr}, \mathrm{Cu}, \mathrm{Ni}, \mathrm{Zn}, \mathrm{Pb}$, As and Se in the roots. Results shown that the highest increase in the percentage of extraction by the shoots were for As and Se and 
by the roots were for As and $\mathrm{Zn}$ in soils amended with both biochars. These results indicate that the combination of Brassica napus and biochar can be a good strategy for the recovery of soils contaminated by heavy metals. The RIII + BM600 treatment reduced the amount of $\mathrm{Cd}$ extracted in the shoots and roots of Brassica napus. This could be a limitation of this assisted phytoremediaton approach in other soils. However, the sampled soil was not contaminated with $\mathrm{Cd}$.

Fig. 3 shows the values of three soil enzymes: phosphomonoesterase, $\beta$-Glucosidase and dehydrogenase. Soil dehydrogenase activity increased after the addition biochars to control soil (RIII). Dehydrogenase activity is an indicator of soil redox status and is involved in soil respiration (Paz-Ferreiro et al., 2012) and it is normally improved by the addition of labile organic carbon (SerraWittling et al., 1996) supplied by the biochar. Biochar BM450 supplied more labile carbon (Cox) and soluble organic carbon (SOC) (see Table 1) than Biochar BM600 and this could be reason of the higher values obtained in dehydrogenase activity after BM450 application. $\beta$-Glucosidase activity diminished after biochar addition. A similar trend has been found in previous studies (Chintala et al., 2014) in two different soils amended with several types of lignocellulose-rich biochars. This result could be explained by the affinity of biochars towards carbon substrates, which would be rendered unavailable for microbial degradation. $\beta$-Glucosidase activity was higher in the RIII + BM600 treatment than in the RIII + BM450 probably due to the reduction of the bioavailability and mobility of metals with the increment of pyrolysis temperature. This fact is very well described in different studies as Méndez et al. (2012) or Cely et al. (2015) that observed a reduction of the bioavailability of heavy metal in biochars prepared from different manure waste (cattle and chicken manure and pig slurry) when pyrolysis temperature increased from 300 to $500^{\circ} \mathrm{C}$. Phosphomonoesterase activity decreased after biochar addition probably caused to the reduction of available $\mathrm{P}$ after biochar addition. Previous works have described similar results, i.e., Gascó et al. (2016) observed a decrement on this activity after application of pig manure biochar (pyrolysis temperature: $500^{\circ} \mathrm{C}$ ) or Paz-Ferreiro et al. (2014) described a decrement on phosphomonoesterase activity after the application of biosolids biochar to a Ferrasols and an Acrisol.

The geometric mean (GMea) of soil enzymes activities has been used previoulsly to estimate the changes on soil quality after biochar addittion (Paz-Ferreiro et al., 2012, 2014; Gascó et al., 2016). Our results showed that GMea was statistically different in the RIII and RIII + BM450 treatments while there was no differences between RIII and RIII + BM600. Therefore, the application of BM450 had a positive effect on soil quality according to previous studies. For example, Paz-Ferreiro et al. (2012) described an increment in GMea after the application of biosolids biochar (pyrolysis temperature: $600^{\circ} \mathrm{C}$ ) to a Umbrisol at a similar rate though Gascó et al. (2016) did not observe any significant difference after the application of pig manune biochar prepared at $300^{\circ} \mathrm{C}$ to a Cambisol. This could indicate that the influence of biochar in soil enzymes depends on different factors, including biochar feedstock, pyrolisys conditions, rate of amendment and soil type. On the other hand, the combination of phytoremediation with Brassica napus and the application of BM450 increased the GMea index indicating an improvement on soil biochemical properties; however, results were enzyme specific. Indeed, Lu et al. (2015) also noted similar results after the combination of Amaranthus tricolor L. with eucalyptus wood biochar and poultry litter biochar attributing partly of the results to increment on soil $\mathrm{pH}$. This $\mathrm{pH}$ variation could be related with the significant increase in soil microbial biomass (Fig. 4) after the application of the two biochars although the sowing of Brassica napus had not a positive effect of microbial biomass. Indeed, there was a reduction on microbial biomass after the combination of Brassica napus and biochars. The positive changes in microbial biomass can be due to biochar being able providing a habitat for soil microbial communities and substrate availability (Kolb et al., 2009).

\section{Conclusions}

The addition of a rabbit manure biochar to a heavy metal multicontaminated soil increased the biomass production of Brassica napus. Our study suggests that assisted phytoremediation using biochar is a feasible approach in the multicontaminated mining soil. Thus, although occasionally, there was a decrease in heavy metal concentrations in plant tissues, overall the application of rabbit manure biochars produced an increment in the total $\mathrm{Cr}, \mathrm{Cu}$, $\mathrm{Ni}, \mathrm{Zn}$, As accumulated in the shoots and in the total Se and of $\mathrm{Co}, \mathrm{Cr}$, $\mathrm{Cu}, \mathrm{Ni}, \mathrm{Zn}, \mathrm{Pb}, \mathrm{As}$ and Se stabilized in the roots. Indeed, the highest percentage of heavy metal extraction by the shoots were for As and Se and by the roots for As and $\mathrm{Zn}$ in soils amended with both biochars.

Positive effects on the GMea index after biochar application indicate that the combination of Brassica napus and biochar could provide additional benefits to the microbial community and be a suitable strategy for the recovery of soil functions in soils contaminated by heavy metals.

Caution should be exerted when extrapolating the results of this study to the field or to other types of biochar. The long-term feasibility of this assisted phytoremediation approach needs to be assessed. In particular, it might be necessary to provide more nutrients (as fertilizer or as biochar) to consistently obtain increased plant biomass yields.

\section{Acknowledgement}

Authors wish to thank to Spanish Ministerio de Economía y Competitividad for economic support (CGL2014-58322-R).

\section{Appendix A. Supplementary data}

Supplementary data to this article can be found online at https://doi.org/10.1016/j.chemosphere.2019.05.168.

\section{References}

Alloway, B.J., 1995. Heavy Metals in Soils. Blackie Academic \& Professional, Chapman \& Hall, London (UK)

Andalucía, Junta de, 2015. Decreto 18/2015, de 27 de enero, por el que se aprueba el reglamento que regula el régimen aplicable a los suelos contaminados. Boletín Oficial de la Junta de Andalucía 38, 28-64.

Bagreev, A., Bandosz, T.J., Locke, D.C., 2001. Pore structure and surface chemistry of adsorbents obtained by pyrolysis of sewage sludge-derived fertilizer. Carbon 39 1971-1979. https://doi.org/10.1016/S0008-6223(01)00026-4.

Baker, A.J.M., Brookes, R.R., 1989. Terrestrial higher plants which hyperaccumulate metallic elements. A review of their distribution, ecology and phytochemistry. Biorecovery 1, 81-126.

Beesley, L., Marmiroli, M., 2011. The immobilisation and retention of soluble arsenic, cadmium and zinc by biochar. Environ. Pollut. 159 (2), 474-480. https://doi.org/ 10.1016/j.envpol.2010.10.016.

Bremner, J.M., 1996. Nitrogen-Total. In: Bigham, J.M. (Ed.), Methods of Soil Analysis. Part 3: Chemical Methods. Madison (USA). SSSA, Madison, pp. 1085-1112.

Camiña, F., Trasar-Cepeda, C., Gil-Sotres, F., Leirós, C., 1998. Measurement of dehydrogenase activity in acid soils rich in organic matter. Soil Biol. Biochem. 30, 1005-1011. https://doi.org/10.1007/s12155-011-9133-7.

Campbell, J., Stark, J.H., Carlton-Smith, C.H., 1997. In: Paper Presented at: Int. Sypm. On Heavy Metals in the Environment, Athens, Greece.

Cely, P., Gascó, G., Paz-Ferreiro, J., Méndez, A., 2015. Agronomic properties of biochars from different manure wastes. J. Anal. Appl. Pyrolysis 111, 173-182. https://doi.org/10.1016/j.jaap.2014.11.014.

Chintala, R., Schumacher, T.E., Kumar, S., Malo, D.D., Rice, J.A., Bleakley, B., Chilom, G., Clay, D.E., Julson, J.L., Papiernik, S.K., Gu, Z.R., 2014. Molecular characterization of biochars and their influence on microbiological properties of 
soil. J. Hazard Mater. 279, 244-256. https://doi.org/10.1016/j.jhazmat.2014.06. 074.

Ehsan, S., Ali, S., Noureen, S., Mahmood, K., Farid, M., Shaque, W., Shakoor, M.B., Rizwan, M., 2014. Citric acid assisted phytoremediation of cadmium by Brassica napus L. Ecotoxicol. Environ. Safety 106, 164-172. https://doi.org/10.1016/j. ecoenv.2015.06.020.

Gascó, G., Paz-Ferreiro, J., Cely, P., Plaza, C., Méndez, A., 2016. Influence of pig manure and its biochar on soil $\mathrm{CO}_{2}$ emissions and soil enzymes. Ecol. Eng. 95, 9-24. https://doi.org/10.1016/j.ecoleng.2016.06.039.

Gulz, P.A., Gupta, S.K., Schulin, R., 2005. Arsenic accumulation of common plants from contaminated soils. Pant Soil 272, 337-347. https://doi.org/10.1007/ s11104-004-5960-z.

Houben, D., Evrard, L., Sonnet, P., 2013. Beneficial effects of biochar application to contaminated soils on the bioavailability of $\mathrm{Cd} . \mathrm{Pb}$ and $\mathrm{Zn}$ and the biomass production of rapeseed (Brassica napus L.). Biomass Bioenerg 57, 196-204. https://doi.org/10.1016/j.biombioe.2013.07.019.

Kabata-Pendias, A., Pendias, H., 2001. Trace Elements in Soils and Plants, third ed. CRC Press, Boca Raton.

Kolb, S.E., Fermanich, K.J., Dornbush, M.E., 2009. Effect of charcoal quantity on microbial biomass and activity in temperate soils. Soil Sci. Soc. Am. J. 73, 1173-1181. https://doi.org/10.2136/sssaj2008.0232.

Lebrun, M., Macri, C., Miard, F., Hattab-Hambli, N., Motelica-Heino, M., Morabito, D. Bourgerie, S., 2017. Effect of biochar amendments on as and $\mathrm{Pb}$ mobility and phytoavailability in contaminated mine technosoils phytoremediated by Salix. J. Geochem. Explor. 182, 149-156. https://doi.org/10.1016/j.gexplo.2016.11.016.

Lebrun, M., Miard, F., Nandillon, R., Leger, J.C., Hattab-Hambli, N., Scippa, G.S., Bourgerie, S., Morabito, D., 2018. Assisted phytostabilization of a multicontaminated mine technosol using biochar amendment: early stage evaluation of biochar feedstock and particle size effects on as and $\mathrm{Pb}$ accumulation of two Salicaceae species (Salix vitaminalis and Populus euramericana). Chemosphere 194, 316-326. https://doi.org/10.1016/j.chemosphere.2017.11.113.

Li, Z., Jia, M., Christie, P., Ali, S., Wu, L., 2018. Use of a hyperaccumulator and biochar to remediate an acid soil highly contaminated with trace metals and/or oxytetracycline. Chemosphere 204, 390-397. https://doi.org/10.1016/j. chemosphere.2018.04.061.

Lu, H., Li, Z., Fu, S., Méndez, A., Gascó, G., Paz-Ferreiro, J., 2015. Combining phytoextraction and biochar addition improves soil biochemical properties in a soil contaminated with Cd. Chemosphere 119, 209-216. https://doi.org/10.1016/j. chemosphere.2014.06.024

Lu, H., Li, Z., Méndez, A., Gascó, G., Paz-Ferreiro, J., 2018. Use of magnetic biochar for the immobilization of heavy metals in a multi-contaminated soil. Sci. Total Environ. 622-623, 892-899. https://doi.org/10.1016/j.scitotenv.2017.12.056.

Marchiol, L., Assolari, S., Sacco, P., Zerbi, G., 2004. Phytoextraction of heavy metals by canola (Brassica napus) and radish (Raphanus sativus) grown on multicontaminated soil. Environ. Pollut. 132, 21-27. https://doi.org/10.1016/j.envpol. 2004.04.001.

McGrath, S.P., Zhao, F.J., 2003. Phytoextraction of metals and metalloids from contaminated soils. Curr. Opin. Biotechnol. 14, 277-282. https://doi.org/10. 1016/S0958-1669(03)00060-0.

McNichol, R.D., Beckett, P.H.T., 1985. Critical tissue concentrations of potentially toxic elements. Plant Soil 85, 107-129. https://doi.org/10.1007/BF02197805.

Méndez, A., Gómez, A., Paz-Ferreiro, J., Gascó, G., 2012. Effects of sewage sludge biochar on plant metal availability after application to a Mediterranean soil. Chemosphere 89 (11), 1354-1359. https://doi.org/10.1016/j.chemosphere.2012. 05.092.

Méndez, A., Terradillos, A., Gascó, G., 2013. Physicochemical and agronomic properties of biochar from sewage sludge pyrolysed at different temperatures. J. Anal. Appl. Pyrolysis 102, 124-130. https://doi.org/10.1016/j.jaap.2013.03.006.

Nelson, D., Sommers, L., 1996. Total carbon, organic carbon and organic matter. In: Bigham, J.M. (Ed.), Methods of Soil Analysis. Part 3: Chemical Methods. Madison (USA). SSSA, Madison, pp. 961-1010.

Novak, J.M., Ippolito, J.A., Ducey, T.F., Watts, D.W., Spokas, K.A., Trippe, K.M Sigua, G.C., Johnson, M.G., 2018. Remediaiton of an acidic mine spoil: Miscanthus biochar and lime amendment affects metal availability, plant growth, and soil enzyme activity. Chemosphere 205, 709-718. https://doi.org/10.1016/j. chemosphere.2018.04.107.

Park, J., Ju-Yong, J., Kyoung-Woong, K., 2012. Phytoremediation of soil contaminated with heavy metals using Brassica napus. Geosystem Engineering 15 (1), 10-18. https://doi.org/10.1080/12269328.2012.674428.

Paz-Ferreiro, J., Trasar-Cepeda, C., Leirós, M.C., Seoane, S., Gil-Sotres, F., 2009.
Biochemical properties in managed grassland soils in a temperate humid zone: modifications of soil quality as a consequence of intensive grassland use. Biol. Fertil. Soils 45, 711-722. https://doi.org/10.1007/s00374-009-0382-y.

Paz-Ferreiro, J., Gascó, G., Gutiérrez, B., Méndez, A., 2012. Soil biochemical activities and the geometric mean of enzyme activities after application of sewage sludge and sewage sludge biochar to soil. Biol. Fertil. Soils 48, 511-517. https://doi.org/ 10.1007/s00374-011-0644-3.

Paz-Ferreiro, J., Lu, H., Fu, S., Méndez, A., Gascó, G., 2014. Use of phytoremediation and biochar to remediate heavy metal polluted soils: a review. Solid Earth 5 , 65-75. https://doi.org/10.5194/se-5-65-2014.

Prasad, M.N.V., 2003. Phytoremediation of metal-polluted ecosystems: hype for commercialization. Russ. J. Plant Physiol. 50, 686-700. https://doi.org/10.1023 A:1025604627496.

Prasad, M.N.V., Freitas, H., 2003. Metal hyperaccumulation in plants-biodiversity prospecting for phytoremediation technology. Electron. J. Biotechnol. 6 285-321. https://doi.org/10.2225/vol6-issue3-fulltext-6.

Puga, A., Carrijo, L., Melo, L.C.A., de Abreu, C.A., Coscione, A.R., Paz-Ferreiro, J., 2016 Leaching and fractionation of heavy metals in mining soils amended with biochar. Soil Tillage Res. 164, 25-33. https://doi.org/10.1016/j.still.2016.01.008.

Rodríguez-Vila, A., Covelo, E.F., Forján, R., Asensio, V., 2015. Recovering a copper mine soil using organic amendments and phytomanagement with Brassica juncea L. J. Environ. Manag. 147, 73-80. https://doi.org/10.1016/j.jenvman.2014. 09.011.

Rossi, G., Fligliolia, A., Socciarelli, S., Pennelli, B., 2002. Capability of Brassica napus to accumulate cadmium, zinc and copper from soil. Acta Biotechnol. 22, 133-140. https://doi.org/10.1002/1521-3846.

Ryan, A., Street-Perrott, A., Eastwood, D., Brackenbury, S., 2014. The Use of Sustainable 'biochar Compost' for Remediation of Contaminated Land. European Geosciences Union General Assembly 2014, Vienna. Austria. Paper presented at.

Serra-Wittling, C., Houot, S., Barriuso, E., 1996. Modification of soil water retention and biological properties by municipal solid waste compost. Compost Sci. Util. 4, 44-52. https://doi.org/10.1080/1065657X.1996.10701817.

Shakoor, M.B., Ali, S., Hameed, A., Farid, M., Hussain, S., Yasmeen, T., Najeeb, U. Bharwana, S.A., Abbasi, G.H., 2014. Citric acid improved lead (Pb) phytoextraction in Brassica napus L. by mitigating pb-induced morphological and biochemical damages. Ecotoxicol. Environ. Saf. 109, 38-47. https://doi.org/10. 1016/j.ecoenv.2014.07.033.

Thornton, I., 1995. Metals in the Global Environment: Facts and Misconceptions. The International Council on Metals in the Environment, Otawa (Canada).

Uchimiya, M., Wartelle, L.H., Klasson, K.T., Fortier, C.A., Lima, I.M., 2011. Influence of pyrolysis temperature on biochar property and function as a heavy metal sorbent in soil. J. Agric. Food Chem. 59, 2501-2510. https://doi.org/10.1021/ jf104206c.

USEPA, 1997. Method 3051A: Microwave Assisted Acid Digestion of Sediments, Sludges, Soils, and Oils. USDA, Washington (USA).

Vance, E.D., Brookes, P.C., Jenkinson, D.J., 1987. An extraction method for measuring soil microbial biomass carbon. Soil Biol. Biochem. 19, 703-707. https://doi.org 10.1016/0038-0717(87)90052-6.

Vangronsveld, J., Herzing, R., Weyens, N., Boulet, J., Adriaensen, K., Ruttens, A., Thewys, T., Vassilev, A., Meers, E., Nehnevajova, E., Van der Lelie, D., Mench, M. 2009. Phytoremediation of contaminated soils and groundwater: lessons from the field. Environ. Sci. Pollut. Res. Int. 16, 765-792. https://doi.org/10.1007/ s11356-009-0213-6.

Wang, K., Zhang, J., Zhu, Z., Huang, H., Li, T., He, Z., Yang, X., Alva, A., 2012. Pig manure vermicompost (PMVC) can improve phytoremediation of $\mathrm{Cd}$ and PAHs co-contaminated soil by Sedum alfredii. J. Soils Sediments 12, 1089-1099. https://doi.org/10.1007/s11368-012-0539-4.

Watanabe, F.S., Olsen, S.R., 1965. Test of an ascorbic acid method for determining phosphorus in water and $\mathrm{NaHCO}_{3}$ extracts from soils. Soil Sci. Soc. Am. Proc. 29 677-678. https://doi.org/10.2136/sssaj1965.03615995002900060025x.

Woolson, E.A., Axley, J.H., Kearney, P.C., 1973. The chemistry and phytotoxicity of arsenic in soils, II effects of time and phosphorus. Soil Sci. Soc. Am. Proc. 37, 254-259.

Yang, D., Zeng, D.H., Li, L., Mao, R., 2012. Chemical and microbial properties in contaminated soils around a magnesite mine in Northeast China. Land Degrad. Dev. 23, 256-262. https://doi.org/10.1002/ldr.1077.

Zaheer, E., Ali, S., Rizwan, M., Farid, M., Shakoor, M.B., Gil, R.A., Najeeb, N., Ahmad, R., 2015. Citric acid assisted phytoremediation of copper by Brassica napus L Ecotox. Environ. Safety 120, 310-317. https://doi.org/10.1016/j.ecoenv.2015.06. 020. 